\title{
EFISIENSI PENGGUNAAN MODEL EOQ (ECONOMIC ORDER QUANTITY) PADA PT. PUSPA MADU SARI SALATIGA
}

\author{
Oleh \\ Matius Rinto Suryanto \\ Alumni UKSW Salatiga \\ Arief Sadjiarto \\ Dosen UKSW Salatiga
}

\begin{abstract}
Abstrak
Penelitian ini ingin mengetahui perbandingan efisiensi manajemen persediaan yang dilakukan oleh PT. Puspa Madu Sari dengan manajemen persediaan model EOQ. Data yang digunakan adalah data sekunder berupa laporan persediaan yang terkait dengan harga bahan, jumlah persediaan bahan, biaya pesan dan biaya simpan persediaan bahan periode tahun 2009.

Hasil penelitian ini menunjukkan bahwa total biaya persediaan yang harus dikeluarkan oleh PT. Puspa Madu Sari untuk periode 2009 sebesar Rp 11,517,462.00 sedangkan hasil perhitungan pada model EOQ, total biaya persediaan hanya sebesar $R p$ 7,507,546.00. Sehingga penerapan model EOQ pada menejemen persediaan PT. Puspa Madu Sari menghasilkan penghematan biaya persediaan sebesar $R p$ 4,009,916.00 atau lebih efisien sebesar 34.8\%. Tidak semua persediaan bahan pada PT. Puspa Madu Sari dalam penentuan jumlah pembeliannya dapat dihitung dengan model EOQ. Untuk itu, PT. Puspa Madu Sari hendaknya melakukan penyesuaian terutama pada parameter yang ada dalam perhitungan EOQ antara lain perkiraan biaya pesan dan biaya simpan.
\end{abstract}

\section{PENDAHULUAN}

Dalam perusahaan, secara umum persediaan biasanya digolongkan dalam persediaan bahan baku atau persediaan bahan mentah, persediaan barang setengah jadi, dan persediaan barang jadi. Masalah produksi merupakan salah satu masalah yang sangat penting bagi perusahaan, karena hal tersebut sangat berpengaruh terhadap laba yang akan diperoleh perusahaan. Apabila proses produksi berjalan dengan lancar maka tujuan perusahaan dapat tercapai. Sedangkan kelancaran dalam proses produksi sangat ditentukan oleh tersedianya persediaan bahan baku dan bahan penolong yang akan diolah. Menurut Zulian Yamit (2005:6) "terdapat empat faktor yang dijadikan sebagai fungsi perlunya persediaan, yaitu faktor waktu, faktor ketidakpastian waktu datang, faktor ketidak pastian penggunaan dalam pabrik, dan faktor ekonomis". Faktor waktu dalam persediaan berkaitan dengan lamanya waktu yang diperlukan dalam satu proses produksi, manajemen harus mampu memperhitungkan jumlah persediaan dengan waktu yang diperlukan dalam satu proses produksi. Persediaan diperlukan untuk memenuhi kebutuhan selama waktu tunggu. Faktor ketidakpastian waktu datang dari suplier, terkadang karena suatu hal suplier tidak dapat mengantarkan pesanan bahan tepat waktu. Persediaan berguna untuk mengantisipasi

Efisiensi Penggunaan Model EOQ (Economic Order Quantity)

Pada PT. Puspa Madu Sari Salatiga (Matius Rinto Suryanto, Arief Sadjiarto) 
keterlambatan bahan dari suplier. Ketidakpastian penggunaan bahan, persediaan dilakukan untuk mengantisipasi ketidaktepatan peramalan produksi. Faktor ekonomis berkaitan dengan jumlah biaya yang akan dikeluarkan oleh perusahaan. Selain hal itu persediaan diperlukan untuk menjaga stabilitas produksi.

Untuk memenuhi kebutuhan proses produksi dalam jangka panjang perusahaan harus membeli bahan baku dalam jumlah yang besar dan menyimpannya digudang. Pembelian bahan baku dalam jumlah yang besar dapat menguntungkan perusahaan karena selain akan mendapatkan potongan harga, juga akan mengatasi masalah kehabisan bahan baku. Dilain pihak jumlah persediaan bahan baku yang terlalu besar akan berakibat pada membengkanya biaya penyimpanan yang harus dikeluarkan oleh perusahaan.

Untuk itu penting bagi perusahaan melakukan pengawasan atas persediaan. Kegiatan ini dapat membantu tercapainya suatu tingkat efisiensi penggunaan dalam persediaan. Dengan adanya kebijakan persediaan bahan yang diterapkan dalam perusahaan, kekurangan bahan dalam proses produksi dan biaya persediaan dapat ditekan sekecil mungkin. Untuk mengantisipasi kekurangan bahan dan meminimumkan biaya dapat digunakan analisis 'Economic Order Quantity' (EOQ). Metode EOQ berusaha mencapai tingkat persediaan yang seminimum mungkin, biaya rendah dan mutu yang lebih baik. Perencanaan metode EOQ dalam suatu perusahaan akan mampu meminimalisasi terjadinya out of stock sehingga tidak mengganggu proses produksi dalam perusahaan dan mampu menghemat biaya persediaan yang dikeluarkan oleh perusahaan karena adanya efisiensi persediaan bahan baku dalam perusahaan.

PT. Puspa Madu Sari merupakan salah satu perusahaan dikota Salatiga yang bergerak dalam bidang produksi. Kegiatan utamanya adalah memproduksi kue Stropwafel (kue khas Belanda). Bahan baku utama yang dipergunakan dalam proses produksi kue ini yaitu terigu, gula, mentega, telur, dan rempah-rempah. Untuk menjaga agar perusahaan dapat terus berproduksi, bahan baku tersebut harus selalu tersedia.

Perhitungan yang pernah dilakukan perusahaan dalam mengadakan pembelian bahan untuk persediaan seperti untuk terigu, perusahaan telah menetapkan jumlah stok maksimum persediaan terigu digudang adalah sebanyak $125 \mathrm{Kg}$, dan stok minimum terigu adalah 50 $\mathrm{Kg}$. Asumsinya stok minimum dapat digunakan untuk produksi selama empat hari kerja dengan jumlah produk 1200 unit per hari. Pada saat stok minimum terigu $50 \mathrm{Kg}$, perusahaan akan membeli terigu sejumlah $75 \mathrm{Kg}$. Berikutnya perhitungan stok telur, karena telur tidak dapat disimpan dalam jangka waktu yang cukup lama, perusahaan tidak berani menyimpan telur dalam jumlah yang cukup banyak. Perusahaan menetapkan persediaan stok maksimum dalam gudang sebanyak $15 \mathrm{Kg}$ dan stok minimum sebanyak lima $\mathrm{Kg}$. Asumsinya stok minimum telur dapat dipergunakan untuk produksi selama dua hari kerja dengan jumlah produk 1200 unit per hari. Pada saat stok minimum telur lima Kg, perusahaan akan membeli telur sejumlah $10 \mathrm{Kg}$.

Berdasarkan latar belakang, ditemukan beberapa gejala problemastis sebagai berikut :

1. Perusahaan masih mengalami kekurangan bahan, terlebih bila terjadi keterlambatan pengiriman bahan dari pemasok. Seperti yang terjadi pada tanggal 12 Januari 2010, pada saat itu perusahaan menargetkan akan memproduksi kue sebanyak 1200 unit karena perusahaan mendapatkan pesanan kue sebanyak 1200 unit, tetapi karena bahan yang tersedia hanya dapat dipergunakan untuk memproduksi sebanyak 600 unit, akhirnya perusahaan hanya memproduksi kue sebanyak 600 unit. Untuk 
memenuhi target (pesanan) tersebut diproduksi pada hari kerja berikutnya setelah bahan baku diperoleh dari pemasok.

2. Pada saat menghadapi waktu-waktu tertentu seperti hari raya, perusahaan sering mengalami hambatan dalam proses produksi. Perusahaan mengalami kesulitan untuk memperoleh bahan baku terutama apabila pemasok yang biasa memasok bahan baku dengan merk tertentu tidak beroperasi. Untuk mempertahankan agar perusahaan tetap dapat berproduksi, biasanya pihak manajemen mencari pemasok lain atau mempergunakan bahan baku yang memiliki kualitas yang hampir sama dengan bahan baku yang biasa dipergunakan oleh perusahaan. Seperti saat menggadapi hari raya pada tahun 2009 untuk stok gula perusahaan mencari pemasok lain (toko Obor) karena pemasok yang biasa (toko Sumber Manis) kehabisan stok gula. Untuk terigu yang dipergunakan oleh perusahaan ternyata yang menyediakan hanya toko Sumber Manis, sehingga jika toko Sumber Manis kehabisan stok terigu perusahaan tidak bisa mencari pemasok lain.

Walaupun perusahaan telah berusaha melakukan manajemen persediaan, namun dalam kenyataannya perusahaan terkadang masih mengalami masalah dalam hal persediaan bahan. Perusahaan ini tidak dapat berproduksi secara maksimal karena terjadi kerkurangan persediaan bahan pada saat melakukan proses produksi. Untuk menentukan kebijakan penyediaan bahan yang tepat dalam arti tidak mengganggu proses produksi dapat dipakai metode EOQ, yaitu jumlah kuantitas bahan yang dapat diperoleh dengan biaya yang minimal setiap kali pembelian. Tehnik EOQ merupakan model persediaan yang membantu menejer dalam pengambilan keputusan mengenai unit yang harus dipesan, agar tidak terjadi investasi yang berlebihan dan agar tidak terjadi kehabisan persediaan yang akan mengakibatkan proses produksi terhenti. Dalam penerapannya, model ini mempertimbangkan baik biayabiaya opearsi maupun biaya financial serta menentukan kuantitas pemesanan yang akan meminimumkan biaya persediaan bahan secara keseluruhan.

Berdasarkan latar belakang dan gejala problematis yang ada maka masalah dalam penelitian ini adalah Bagaimanakah efisiensi manajemen persediaan yang dilakukan oleh PT. Puspa Madu Sari dibandingkan dengan manajemen persediaan model EOQ?. Sedangkan tujuannya untuk mengetahui perbandingan efisiensi antara manajemen persediaan yang dilakukan oleh PT. Puspa Madu Sari dengan manajemen persediaan model EOQ. Penelitian ini memiliki keterbatasan antara lain biaya simpan per unit diambil dari rata-rata biaya listrik dan biaya sewa gedung dan tidak dicantumkan data hasil perhitungan biaya persediaan periode sebelumnya, sehingga tidak bisa diketahui bagaimana tren biaya persediaan dari tahun ketahun serta penelitian ini hanya menfokuskan pada data sekunder berupa data hasil perhitungan pada periode 2009 saja.

\section{KAJIAN PUSTAKA Manajemen}

Setiap perusahaan tentunya bertujuan untuk memperoleh laba. Agar dapat mencapai tujuannya haruslah ada kerjasama di dalam perusahaan tersebut. Agar dalam perusahaan dapat terjalin hubungan kerjasama, peran manajemen sangat dibutuhkan. Manajemen merupakan upaya menyelesaikan sesuatu melalui orang lain atau mengerjakan sesuatu dengan bantuan atau kerja sama orang lain. Sebagaimana dikemukakan oleh Nickels, 
McHugh and McHugh dalam Tisnawati Sule, Erni dan Kurniawan Saefullah, (2005:5) bahwa "Manajemen adalah sebuah proses yang dilakukan untuk mewujudkan tujuan organisasi melalui rangkaian kegiatan berupa perencanaan, pengorganisasian, pengarahan, dan pengendalian orang-orang serta sumber daya organisasi lainya". Manajemen merupakan rangkaian kegiatan perencanaan, pengorganisasian, pengarahan dan pengendalian yang bertujuan untuk mencapai tujuan suatu organisasi.

\section{Persediaan}

Setiap perusahaan yang menyelenggarakan kegiatan produksi pasti akan memerlukan persediaan bahan baku. Tersedianya persediaan bahan baku dalam perusahaan, diharapkan perusahaan dapat melakukan proses produksi sesuai kebutuhan atau permintaan konsumen. Adanya persediaan bahan baku yang tersedia di gudang juga diharapkan dapat memperlancar kegiatan produksi perusahaan dan dapat menghindari terjadinya kekurangan bahan baku.

Menurut Arman Hakim Nasution dan Yudha Prasetyawan (2008:113), "persediaan adalah sumber daya menganggur (idle resources) yang menunggu proses lebih lanjut".

\section{Jenis Persediaan}

Dalam perusahaan manufaktur, menurut Arman Hakim Nasution dan Yudha Prasetyawan (2008:113) ada empat jenis persediaan yaitu:

"1). Bahan baku (raw materials) adalah barang-barang yang dibeli dari pemasok (supplier) dan akan digunakan atau diolah menjadi produk jadi yang akan dihasilkan oleh perusahaan.

2). Bahan setengah jadi (work in process) adalah bahan baku yang sudah diolah atau dirakit menjadi komponen namun masih membutuhkan langkah-langkah lanjutan agar menjadi produk jadi.

3). Barang jadi (finished goods) adalah barang jadi yang telah selesai diproses, siap untuk disimpan di gudang barang jadi, dijual, atau didistribusikan ke lokasi-lokasi pemasaran.

4). Bahan-bahan pembantu (supplies) adalah barang-barang yang dibutuhkan untuk menunjang produksi, namun tidak akan menjadi bagian pada produk akhir yang dihasilkan perusahaan".

Bahan baku merupakan barang-barang yang akan diolah oleh perusahaan untuk menjadi bahan setengah jadi atau bahan jadi. Karena penggunaanya dalam proses pengolahan relatif besar, bahan baku dengan mudah dapat diikuti biayanya. Dalam proses pengolahan, perusahaan membutuhkan bahan penolong sebagai penunjangnya, namun karena jumlahnya relatif kecil bahan penolong sulit diikuti biayanya. Barang setengah jadi merupakan bahan yang masih membutuhkan proses lanjutan untuk menjadi barang jadi. Sedangkan barang jadi adalah hasil olahan bahan baku atau pun barang setengah jadi yang siap untuk dipasarkan atau didistribusikan. 


\section{Tujuan Diadakannya Persediaan}

Pada prinsipnya semua perusahaan yang melaksanakan proses produksi akan menyelenggarakan persediaan bahan baku untuk kelangsungan proses produksi dalam perusahaan tersebut. Tujuan diadakanya persediaan bahan menurut Zulian Yamit (2005: 9) adalah,

“1). Untuk memberikan layanan yang baik bagi pelanggan konsumen.

2). Untuk memperlancar proses produksi.

3). Untuk mengantisipasi kemungkinan terjadinya kekurangan persediaan.

4). Untuk menghadapi fluktuasi harga"

Menyediakan persediaan yang memadai bagi perusahaan dapat memberikan layanan yang baik kepada pelanggan karena dapat memenuhi permintaan konsumen, memperlancar proses produksi karena bahan yang selalu tersedia serta dapat mengantisipasi kemungkinan terjadinya kekurangan persediaan. Selain itu, perusahaan menyediakan persediaan untuk tujuan agar dapat menghadapi fluktuasi harga. Oleh karena itu, tersedianya persediaan bahan baku untuk keperluan produksi merupakan suatu hal yang mutlak diperlukan.

\section{Biaya-Biaya Dalam Persediaan}

Perusahaan harus memperhatikan biaya-biaya variabel yang terkait dengan persediaan, biaya-biaya tersebut menurut Zulian Yamit (2005: 9) antara lain;

"1). Biaya pembelian (purchase cost) adalah harga per unit apabila item dibeli dari pihak luar, atau biaya produksi per unit apabila diproduksi dalam perusahaan.

2). Biaya pemesanan (order cost/setup cost) adalah biaya yang berasal dari pembelian pesanan dari supplier atau biaya persiapan (setup cost) apabila item diproduksi dalam perusahaan.

3). Biaya simpan (carriying cost/holding cost) adalah biaya yang dikeluarkan atas investasi dalam persediaan dan pemeliharaan maupun investasi sarana fisik untuk menyimpan persediaan.

4). Biaya kekurangan persediaan (stockout cost) adalah konsekuensi ekonomis atas kekurangan dari luar maupun dari dalam perusahaan".

Biaya persediaan merupakan biaya-biaya yang harus dikeluarkan oleh perusahaan mulai dari pengadaan persediaan sampai saat pada saat persdiaan akan dipergunakan dalam kegiatan perusahaan. Biaya-biaya untuk menyelenggarakan persediaan bahan baku sudah selayaknya diperhitungkan dalam penentuan besarnya persediaan bahan baku, karena besar kecilnya biaya persediaan baku pada akhirnya akan mempengaruhi laba yang akan diperoleh perusahaan.

\section{Manajemen Persediaan}

Menurut Richardus Eko Indrajit (2003:4) "manajemen persediaan (inventory control) atau disebut juga inventory management atau pengendalian tingkat persediaan adalah kegiatan yang berhubungan dengan perencanaan, pelaksanaan, dan pengawasan penentuan kebutuhan material sedemikian rupa sehingga di satu pihak kebutuhan operasi dapat dipenuhi pada waktunya dan di lain pihak investasi persediaan material dapat ditekan secara optimal.”

Efisiensi Penggunaan Model EOQ (Economic Order Quantity) 
Manajemen persediaan merupakan suatu usaha yang berkaitan dengan kegiatan perencanaan, pengorganisasian, pelaksanaan, dan pengawasan persediaaan untuk menghindari kekurangan bahan yang dibutuhkan dengan tidak terlalu banyak modal terkait padanya agar tujuan perusahaan dapat tercapai. Aktivitas manajemen persediaan berawal dari rencana operasi. Rencana operasi ini memberikan uraian mengenai kebutuhankehutuhan yang diperlukan untuk menunjang kelancaran produksi serta memuat spesifikasi mengenai berapa banyak persediaan yang sebaiknya dimiliki, kapan sebaiknya membeli dan berapa biaya yang harus dikeluarkan.

\section{Efektivitas dan Efisiensi Persediaan}

Richardus Eko Indrajit (2003:11) berpendapat mengenai persediaan barang ada sejenis prinsip pengelolaan yang harus dianut, yakni: "penentuan jumlah dan jenis barang yang disimpan dalam persediaan haruslah sedemikian rupa sehingga produksi dan operasi perusahaan tidak terganggu, tetapi dilain pihak sekaligus harus dijaga agar biaya investasi yang timbul dari penyediaan barang tersebut seminimal mungkin."

Dengan demikian secara umum kelancaran produksi dan opersi perusahaan merujuk pada soal efektivitas persediaan. Sedangkan efisiensi persediaan merujuk pada perbandingan antara pemakaian bahan baku atau jumlah bahan baku yang dibutuhkan dengan biaya persediaan.

\section{Model Persediaan}

Model persediaan untuk permintaan independen ada tiga yaitu;

1). Model dasar Economic Order Quantity (EOQ). "Perngertian EOQ sebenarnya adalah merupakan volume atau jumlah pembelian yang paling eonomis untuk dilaksanakan pada setiap kali pembelian. Model ini dapat digunakan baik untuk barang yang dibeli maupun untuk barang yang diproduksi sendiri”. (Gitosudarmo, Indriyo dan Agus Mulyono, 2000:218)

2). Model Production Order Quantity. Model production order quantity cocok diterapkan untuk lingkungan produksi, dan dikenal dengan sebutan model jumlah produksi. Model production order quantity dapat diterapkan saat persediaan secara terus-menerus terbentuk sepanjang waktu. Model ini dibuat dengan menetapkan biaya pemesanan sama dengan biaya penyimpanan.

3). Model Quantity Discount. Model quantity discount merupakan pengurangan harga untuk barang yang dibeli dengan jumlah yang lebih besar. Sehingga akan terdapat daftar potongan harga dengan berbagai potongan untuk pesanan-pesanan dalam jumlah besar. (Yenny Purwanti, 200 ,124)

Model-model persediaan memiliki tujuan untuk meminimumkan biaya total. Penggunaan model persediaan hendaknya disesuaikan dengan jenis perusahaan, sehingga tujuan manajemen persediaan pada perusahaan yang bersangkutan dapat tercapai.

\section{Metode EOQ (Economic Order Quantity)}

Perencanaan metode EOQ dalam suatu perusahaan akan mampu meminimalisasi terjadinya out of stock sehingga tidak mengganggu proses produksi dalam perusahaan dan 
mampu menghemat biaya persediaan yang dikeluarkan oleh perusahaan karena adanya efisiensi persediaan bahan dalam perusahaan. Selain memperhitungkan jumlah pembeliaan yang tepat dan perhitungan biaya persediaan bahan, metode EOQ juga memperhitungkan frekuensi pembelian persediaan bahan yang paling tepat untuk dilaksanakan dalam satu periode serta memperhitungkan jarak siklus waktu pembelian persediaan agar dalam perusahaan tidak terjadi keterlambatan pengiriman persediaan bahan.

Pada metode EOQ jumlah pembelian yang paling ekonomis adalah dimana total biaya pesan sama dengan total biaya simpan.Setiap kali perusahaan melakukan pengadaan persediaan tentunya perusahaan akan mengeluarkan biaya. Dalam metode EOQ hanya terdapat dua karegori biaya yang relevan untuk dipertimbangkan, yaitu biaya pesan dan biaya simpan, karena stockout cost dan biaya perubahan kapasitas tidak akan terjadi apabila permintaan konstan (salah satu asumsi dalam model EOQ). Dalam perusahaan, biaya pemesanan ini biasanya berupa biaya telepon, biaya angkut, biaya transportasi. Setelah barang yang dipesan sampai diperusahaan tentunya perusahaan akan melakukan penyimpanan. Dalam rangka melakukan penyimpanan barang, perusahaan akan mengeluarkan biaya penyimpanan. Biaya penyimpanan ini biasanya berupa biaya sewa gudang, biaya perawatan gudang, biaya listrik untuk penyimpanan.

\section{Asumsi Model EOQ}

Teknik ini relatif mudah digunakan, tetapi menurut Render, Barry dan Jay Heizer, 2001:320 harus didasarkan pada beberapa asumsi :

"1).Tingkat permintaan diketahui dan bersifat konstan.

2). Lead time, yaitu waktu antara pemesanan dan penerimaan pesanan, diketahui, dan bersifat konstan.

3). Persediaan diterima dengan segera. Dengan kata lain, persediaan yang dipesan tiba dalam bentuk kumpulan produk, pada satu waktu.

4). Tidak mungkin diberikan diskon.

5). Biaya variable yang muncul hanya biaya pemasangan atau pemesanan dan biaya penahanan atau penyimpanan persediaan sepanjang waktu.

6). Keadaan kehabisan stok (kekurangan) dapat dihindari sama sekali bila pemesanan dilakukan pada waktu yang tepat".

Suatu perusahaan dapat dengan mudah mempergunakan metode EOQ dalam penentuan persediaan apabila perusahaan tersebut dapat memenuhi asumsi-asumi metode EOQ. Asumsi-asumsi diatas merupakan rambu-rambu yang harus dipenuhi agar perusahaan dapat menerapkan EOQ dalam memanajemen persediaan.

\section{Studi Terdahulu}

Bahasan tentang manajemen persediaan ditemui antara lain:

1. Penelitian yang dilakukan oleh Prakoso Aditomo (2007), tentang efisiensi penggunaan metode EOQ (Economic Order Quantity) dalam perolehan laba pada CV Nandy Astika Wonogiri. Hasil menunjukkan manajemen persediaan bahan baku kayu mahoni yang diterapkan pada CV Nandy Astika Wonogiri masih tergolong sederhana karena tidak menerapkan sistem manajemen persediaan seperti EOQ, POQ dan lain-lain. Efisiensi yang mereka dapatkan adalah dari biaya transportasi yang sudah ditanggung oleh supplier. Efisiensi bahan baku kayu mahoni yang dihitung dengan model EOQ pada CV 
Nandy Astika Wonogiri akan diperoleh dari efisiensi biaya simpan saja, karena perhitungan efisiensi biaya pesan antara model EOQ dengan yang dilakukan oleh $\mathrm{CV}$ Nandy Astika Wonogiri lebih besar dari pada model EOQ, sehingga apabila perusahaan tersebut menerapkan model EOQ akan memperoleh efisiensi yang lebih besar dari biaya simpan.

2. Penelitian yang dilakukan oleh Fany Darmawati Surja (2002), tentang analisis pengendalian persediaan bahan pada Perusahaan Sandal OMICA Semarang, Kesimpulan yang diperoleh biaya persediaan bahan baku dengan menggunakan model EOQ lebih hemat bila dibandingkan biaya persediaan bahan baku yang dilakukan oleh perusahaan. Bahwa dengan menggunakan model EOQ maka terdapat penghematan biaya bahan baku sebesar $22,67 \%-28,47 \%$.

3. Penelitian yang dilakukan oleh Ellen Novilensia Kurmasela (2004), tentang manajemen sediaan bahan baku kapas pada departemen spinning - PT Daya Manunggal Salatiga. Hasil yang diperoleh adalah tingkat efisiensi yang diperoleh berdasarkan hasil perhitungan EOQ diketahui TIC (total biaya) bahan baku bulan Desember 2002 sampai November 2003, yaitu sebesar \$ 9.993.36.

Dari hasil ketiga penelitian terdahulu, dapat ditarik kesimpulan bahwa penggunaan model EOQ dalam manajemen persediaan dapat menghasilkan tingkat efisiensi baik dari biaya pesan maupun biaya simpan. Sehingga, secara keseluruhan penggunaan model EOQ dalam menejemen persediaan akan lebih meningkatkan efisiensi biaya persediaan. Selain hal itu, penggunaan manajemen persediaan model EOQ juga meningkatkan efektifitas persediaan bahan dalam menunjang kegiatan perusahaan.

\section{Kerangka Penelitian}

Dalam rangka menjaga kelancaran kegiatan produksi perusahaan, bahan baku yang dibutuhkan hendaknya cukup tersedia, akan tetapi hendaknya jumlah persediaan jangan terlalu besar sehingga modal yang tertanam dan biaya yang ditimbulkan dengan adanya persediaan juga tidak besar. Untuk menentukan kebijakan penyediaan bahan yang tepat dalam arti tidak mengganggu proses produksi dapat dipakai metode EOQ, yaitu jumlah kuantitas bahan yang dapat diperoleh dengan biaya yang minimal setiap kali pembelian. Tehnik EOQ merupakan model persediaan yang memiliki komponen yang perlu diperhitungkn yaitu jumlah pemesanan, biaya pemesanan, dan biaya penyimpanan. Tehnik EOQ berusaha menjawab berapa jumlah pembeliaan persediaan yang paling ideal yang harus dilakukan oleh perusahaan. Persediaan yang paling ideal merujuk pada efektifitas penggunaan persediaan. Jumlah pemesanan yang tepat untuk tercapainya tujuan produksi dan efisiensi persediaan merujuk pada biaya yang digunakan dalam hal ini biaya pemesanan dan biaya penyimpanan. Apabila digambarkan dalam skema, maka skema kerangka penelitian ini adalah sebagai berikut: 


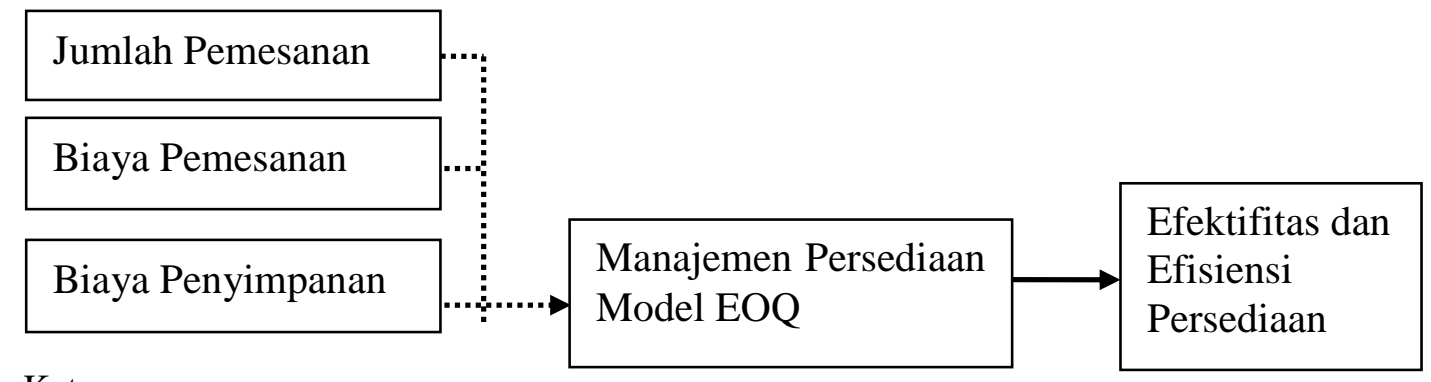

Keterangan :

$\ldots \ldots . . . \rightarrow$ : input ke proses

$\longrightarrow$ : proses ke output

Gambar 1. Kerangka Penelitian

\section{METODOLOGI PENELITIAN}

\section{Metode Penelitian}

Jenis penelitian yang digunakan dalam penelitian ini adalah jenis penelitian deskriptif. Ronny Kountur (2004:34) mengatakan bahwa, penelitian deskriptif adalah "jenis penelitian yang memberikan gambaran atau uraian atas suatu keadaan yang jelas mungkin tanpa ada perlakuan terhadap obyek yang diteliti'. Penelitian deskriptif dalam penelitian ini adalah memberikan gambaran tentang perbandingan efisiensi manajemen persediaan yang diterapkan oleh PT. Puspa Madu Sari dengan manajemen persediaan model EOQ.

\section{Obyek Penelitian}

Obyek penelitian dalam penelitian ini adalah laporan persediaan PT. Puspa Madu Sari Salatiga periode pembukuan bulan Januari 2009 sampai dengan bulan Desember 2009.

\section{Jenis Data}

Data penelitian ini berupa laporan persediaan yang terkait dengan harga per gram bahan baku, jumlah persediaan bahan, biaya pesan dan biaya simpan bahan baku yang dihitung selama periode tahun 2009 yang telah disajikan oleh PT. Pupa Madu Sari Salatiga.

\section{E. Definisi Operasional}

Pada penelitian ini variabel yang ingin dianalisis adalah perbandingan efisiensi antara manajemen persediaan yang dilakukan oleh PT. Puspa Madu Sari dengan manajemen persediaan model EOQ yang meliputi:

1. Jumlah pesanan ekonomis adalah jumlah pesanan yang dapat menyeimbangkan biaya pesan dan biaya simpan.

2. Biaya pesan optimum adalah biaya pesan yang harus dikeluarkan perusahaan, apabila perusahaan melakukan pemesanan dengan jumlah pesanan ekonomis.

3. Biaya simpan optimum adalah biaya yang harus dikeluarkan perusahaan, apabila perusahaan melakukan pemesanan dengan jumlah pesanan ekonomis. 
4. Total biaya persediaan (minimum) adalah jumlah biaya pesan optimum ditambah dengan jumlah biaya simpan optimum.

5. Frekuensi pemesanan adalah jumlah pembelian yang harus dilakukan dalam satu periode.

6. Jarak siklus (waktu) adalah jarak waktu pembelian pertama dengan pembelian selanjutnya yang harus dilakukan dalam satu periode.

\section{Teknik Analisis Data}

Teknik analisis data dalam penelitian ini dibagi dalam tiga tahapan:

1. Mendeskripsikan perhitungan persediaan bahan dan besarnya biaya-biaya persediaan yang dilakukan oleh PT. Puspa Madu Sari.

2. Analisis perhitungan persediaan dan besarnya biaya persediaan dengan model EOQ yaitu menghitung hal-hal sebagai berikut:

EOQ dapat dihitung dengan mudah dengan menggunakan persamaan berikut :

EOQ atau $Q^{*}=$

Jumlah pemesanan yang ekonomis selanjutnya digunakan untuk menghitung:

Biaya pesan optimum : ( ) $(\mathrm{S})$

Biaya simpan optimum: $(\quad) \cdot(\mathrm{C})$

Total biaya persediaan (minimum) TC min $:(\quad) \cdot(\mathrm{S})+(\quad) \cdot(\mathrm{C})$

Frekuensi pesanan optimum per periode $\quad:\left(\frac{R}{Q_{*}}\right)$

Jarak siklus (waktu) $\quad:\left(\frac{Q^{*}}{R}\right)$

Notasi-notasi yang digunakan dalam persamaan adalah :

$\mathrm{R} \quad$ : jumlah pembelian (permintaan) selama satu periode

C : biaya penyimpanan tahunan dalam rupiah / unit

$\mathrm{S} \quad$ : biaya setiap kali pemesanan

Q : : kuantitas pemesanan (unit/order)

Q* : jumlah pemesanan optimum (EOQ)

3. Membandingkan hasil analisis penghitungan persediaan yang dilakukan oleh PT. Puspa Madu Sari dengan penghitungan persediaan dengan model EOQ, untuk mengetahui perbandingan tingkat efisiensi manajemen persediaan bahan baku yang diterapkan PT. Puspa Madu Sari dengan manajemen persediaan model EOQ.

\section{HASIL TEMUAN DAN PEMBAHASAN}

\section{Gambaran Obyek Penelitian}

PT. Puspa Madu Sari adalah salah satu perusahaan yang bergerak dalam bidang produksi makanan yang berupa kue Stroopwafel yaitu salah satu makanan khas belanda. 
Produk ini dikalangan masyarakat masih tergolong baru karena sampai saat ini hanya terdapat satu hanya ada satu perusahaan Belanda yang juga memproduksi kue serupa dan dipasarkan di Starbucks dan beberapa supermarket lain di Jakarta. Visi PT. Puspa Madu Sari sendiri yaitu agar produknya dikenal oleh kalangan menengah ke atas di Indonesia. Sedangkan tujuan yang ingin dicapai adalah untuk memberikan produk dengan kualitas terbaik.

Jumlah kue yang diproduksi rata-rata dalam satu tahun oleh PT. Puspa Madu Sari sebanyak 229.350 unit. Jumlah produksi kue tertinggi dalam satu hari kerja sebanyak 3.600 unit, jumlah ini biasanya terjadi pada saat waktu-waktu tertentu misalnya pada saat mendekati hari-hari besar. Jumlah produksi terendah dalam satu hari kerja sebanyak 300 unit, jumlah ini hanya untuk memenuhi pesanan yang berasal dari cafe-cafe atau supermarket tertentu yang menjadi area pemasaran produk.

\section{Persediaan}

Setiap perusahaan yang menyelenggarakan kegiatan produksi pasti akan memerlukan persediaan bahan baku, demikian juga dengan PT. Puspa Madu Sari yang bergerak dalam kegiatan prodiksi kue. Tersedianya persediaan bahan baku dalam perusahaan akan memperlancar proses produksi, dan dapat menghindari terjadinya kekurangan bahan baku. Persediaan bahan baku PT. Puspa Madu Sari secara umum untuk periode 2009 dapat dilihat pada tabel berikut.

Tabel 1. Persediaan PT. Puspa Madu Sari periode 2009

\begin{tabular}{|l|l|c|c|c|c|c|}
\hline No & \multicolumn{1}{|c|}{ Jenis Bahan } & $\begin{array}{c}\text { Kebutuhan } \\
\text { ratarata/thn } \\
\text { (gram) }\end{array}$ & $\begin{array}{c}\text { Kebutuhan } \\
\text { rata-rata/bln } \\
\text { (gram) }\end{array}$ & $\begin{array}{c}\text { Harga } \\
\text { rata- } \\
\text { rata per } \\
\text { Unit } \\
\text { (Rp) }\end{array}$ & $\begin{array}{c}\text { Biaya } \\
\text { pesan per } \\
\text { Order } \\
\text { (Rp) }\end{array}$ & $\begin{array}{c}\text { Biaya } \\
\text { simpan } \\
\text { per unit } \\
\text { (Rp) }\end{array}$ \\
\hline 1 & Terigu & 2.238 .700 & $186.558,33$ & 6,45 & 15.000 & 0,89 \\
2 & Telur & 494.618 & $41.218,17$ & 11,33 & 15.000 & 0,89 \\
3 & Gula 'GP' & 557.800 & $46.483,33$ & 18,86 & 60.000 & 0,89 \\
4 & Gula 'PS' & 645.570 & $53.797,50$ & 7,02 & 15.000 & 0,89 \\
5 & Gula 'SJ' & 242.028 & 20.169 & 9,90 & 80.000 & 0,89 \\
6 & Mentega 'BB' & 1.187 .404 & $98.950,33$ & 13,31 & 62.500 & 0,89 \\
7 & Mentega 'B' & 293.560 & $24.463,33$ & 49,42 & 62.500 & 0,89 \\
8 & Glukosa 'GE' & 1.318 .519 & $109.876,58$ & 3,33 & 12.000 & 0,89 \\
9 & Glukosa 'FE' & 105.000 & 8.750 & 8,97 & 62.500 & 0,89 \\
10 & Glukosa 'DE' & 121.454 & $10.121,17$ & 7,49 & 62.500 & 0,89 \\
11 & Penambah Aroma 'A' & 1.396 & 116,33 & 373,59 & 50.000 & 0,89 \\
12 & Penambah Aroma 'B' & 830 & 69,17 & 183,66 & 62.500 & 0,89 \\
13 & Rempah 'A' & 81.220 & $6.768,33$ & 52,29 & 50.000 & 0,89 \\
14 & Rempah 'B' & 2.870 & 239,17 & 55,65 & 50.000 & 0,89 \\
\hline
\end{tabular}

Sumber : Data sekunder diolah, 2010

Dari tabel tersebut, dapat diketahui jumlah unit rata-rata masing-masing bahan yang dibutuhkan dalam satu tahun, jumlah unit rata-rata yang dibutuhkan dalam satu bulan, harga rata-rata masing-masing bahan per unit, biaya pesan per order untuk masing-masing bahan dan biaya simpan per unit masing-masing bahan. Data tersebut selanjutnya dipergunakan untuk mencari biaya pesan per periode, biaya simpan per periode serta total biaya persediaan per periode yang harus dikeluarkan oleh perusahaan. 


\section{Perhitungan Biaya Pesan}

Besarnya biaya untuk pemesanan bahan selama periode 2009 pada PT. Puspa Madu Sari dapat dilihat pada tabel berikut ini.

Tabel 2. Biaya Pemesanan Bahan PT Puspa Madu Sari periode 2009

\begin{tabular}{|c|c|}
\hline Jenis Bahan & Jumlah (Rp) \\
\hline Terigu & $660.000,00$ \\
\hline Telur & $735.000,00$ \\
\hline Gula 'GP' & $300.000,00$ \\
\hline Gula 'PS' & $180.000,00$ \\
\hline Gula 'SJ' & $240.000,00$ \\
\hline Mentega 'BB' & $625.000,00$ \\
\hline Mentega 'B' & $687.500,00$ \\
\hline Glukosa 'GE' & $276.000,00$ \\
\hline Glukosa 'FE' & $375.000,00$ \\
\hline Glukosa 'DE' & $375.000,00$ \\
\hline Penambah Aroma 'A' & $150.000,00$ \\
\hline Penambah Aroma 'B' & $125.000,00$ \\
\hline Rempah 'A' & $200.000,00$ \\
\hline Rempah 'B' & $100.000,00$ \\
\hline Jumlah & $\mathbf{5 . 0 2 8 . 5 0 0 , 0 0}$ \\
\hline
\end{tabular}

Sumber : Data sekunder diolah, 2010

Tabel 2 diatas adalah rincian biaya pemesanan yang dikeluarkan oleh perusahaan hasil dari penghitungan biaya pesan per order dikali dengan frekuensi pemesanan yang dilakukan oleh perusahaan selama satu tahun. Jumlah total biaya pemesanan yang harus dikeluarkan oleh perusahaan selama periode 2009 sebesar Rp 5.028.500,00.

\section{Perhitungan Biaya Simpan}

Biaya simpan yang dikeluarkan oleh perusahaan merupakan biaya-biaya yang berhubungan utuk penyimpanan misalnya biaya listrik, biaya sewa gudang serta biaya-biaya lainnya yang berhubungan dengan penyimpanan bahan.

Tabel Biaya Simpan PT. Puspa Madu Sari periode 2009

\begin{tabular}{|c|c|}
\hline Jenis Bahan & Jumlah (Rp) \\
\hline Terigu & $1.992 .443,18$ \\
\hline Telur & $440.209,81$ \\
\hline Gula 'GP' & $496.442,00$ \\
\hline Gula 'PS' & $574.557,30$ \\
\hline Gula 'SJ' & $215.404,92$ \\
\hline Mentega 'BB' & $1.056 .789,56$ \\
\hline Mentega 'B' & $261.268,37$ \\
\hline Glukosa 'GE' & $1.173 .481,85$ \\
\hline Glukosa 'FE' & $93.450,00$ \\
\hline Glukosa 'DE' & $108.094,04$ \\
\hline Penambah Aroma 'A' & $1.242,43$ \\
\hline Penambah Aroma 'B' & 738,70 \\
\hline Rempah 'A' & $72.285,80$ \\
\hline Rempah 'B' & 2554,30 \\
\hline Jumlah & $6.488 .962,26$ \\
\hline
\end{tabular}


Sumber : Data sekunder diolah, 2010

Tabel 3 merupakan hasil penghitungan dari jumlah rata-rata per order dikali jumlah frekuensi pemesanan dikali biaya simpan per unit. Jumlah biaya simpan yang harus ditanggung perusahaan selama periode 2009 dibulatkan menjadi sebesar Rp 6.488.962,00.

\section{Jumlah Biaya Persediaan}

Pada PT. Puspa Madu Sari jumlah total biaya persediaan berasal dari biaya pengadaan bahan atau biaya pemesanan dan biaya penyimpanan bahan.

Tabel 4. Total Biaya Persediaan

PT. Puspa Madu Sari periode 2009

\begin{tabular}{|c|c|}
\hline Jenis Bahan & Jumlah (Rp) \\
\hline Terigu & $2.652 .443,18$ \\
\hline Telur & $1.175 .209,81$ \\
\hline Gula 'GP' & 796.442 \\
\hline Gula 'PS' & $754.557,30$ \\
\hline Gula 'SJ' & $455.404,92$ \\
\hline Mentega 'BB' & $1.681 .789,56$ \\
\hline Mentega 'B' & $948.768,37$ \\
\hline Glukosa 'GE' & $1.449 .481,85$ \\
\hline Glukosa 'FE' & 468.450 \\
\hline Glukosa 'DE' & $483.094,04$ \\
\hline Penambah Aroma 'A' & $151.242,43$ \\
\hline Penambah Aroma 'B' & $125.738,70$ \\
\hline Rempah 'A' & $272.285,80$ \\
\hline Rempah 'B' & $102.554,30$ \\
\hline Jumlah & $11.517 .462,26$ \\
\hline
\end{tabular}

Sumber : Data sekunder diolah, 2010

Tabel 4 menunjukkan hasil total persediaan yang berasal dari penjumlahan antara biaya pesan dan biaya simpan.

\section{Frekuensi Pemesanan Persediaan}

Frekuensi pemesanan bertujuan untuk mencegah terjadinya pemesanan yang mendadak sehingga tidak terjadi kekurangan bahan dalam proses produksi. Frekuensi pemesanan bahan PT. Puspa Madu Sari pada periode 2009 dapat dilihat pada tabel berikut ini. 
Tabel 5. Frekuensi Pemesanan Persediaan T. Puspa Madu Sari periode 2009

\begin{tabular}{|l|c|}
\hline \multicolumn{1}{|c|}{ Jenis Bahan } & Jumlah (Rp) \\
\hline Terigu & 44 \\
Telur & 49 \\
Gula 'GP' & 5 \\
Gula 'PS' & 12 \\
Gula 'SJ' & 3 \\
Mentega 'BB' & 10 \\
Mentega 'B' & 11 \\
Glukosa 'GE' & 23 \\
Glukosa 'FE' & 6 \\
Glukosa 'DE' & 6 \\
Penambah Aroma 'A' & 3 \\
Penambah Aroma 'B' & 2 \\
Rempah 'A' & 4 \\
Rempah 'B' & 2 \\
\hline
\end{tabular}

Sumber : Data sekunder diolah, 2010

\section{Perhitungan Persediaan Menggunakan Model EOQ}

Perusahaan hendaknya menggunakan metode dalam memanajemen persediaan, penggunaan metode tersebut diharapkan dapat membantu perusahaan mencapai efektifitas dan efisiensi baik dalam jumlah unit persediaan maupun dalam jumlah nominal biaya. Berikut merupakan hasil perhitungan apabila persediaan PT. Puspa Madu Sari dihitung dengan menggunakan metode EOQ.

Tabel 6. Perhitungan EOQ Persediaan PT. Puspa Madu Sari periode 2009

\begin{tabular}{|l|l|c|c|c|c|}
\hline No & \multicolumn{1}{|c|}{ Jenis Bahan } & $\begin{array}{c}\text { Kebutuhan } \\
\text { rata-rata/thn } \\
\text { (gram) }\end{array}$ & $\begin{array}{c}\text { Biaya pesan } \\
\text { per Order } \\
\text { (Rp) }\end{array}$ & $\begin{array}{c}\text { Biaya simpan } \\
\text { per unit } \\
\text { (Rp) }\end{array}$ & $\begin{array}{c}\text { EOQ } \\
\text { (gram) }\end{array}$ \\
\hline 1 & Terigu & 2.238 .700 & 15.000 & 0,89 & 274.203 \\
2 & Telur 'GP' & 494.618 & 15.000 & 0,89 & 129.122 \\
3 & Gula 'GP' & 557.800 & 60.000 & 0,89 & 274.243 \\
4 & Gula 'PS' & 645.570 & 15.000 & 0,89 & 147.515 \\
5 & Gula 'SJ' & 242.028 & 80.000 & 0,89 & 208.592 \\
6 & Mentega 'BB' & 1.187 .404 & 62.500 & 0,89 & 408.375 \\
7 & Mentega 'B' & 293.560 & 62.500 & 0,89 & 203.053 \\
8 & Glukosa 'GE' & 1.318 .519 & 12.000 & 0,89 & 188.562 \\
9 & Glukosa 'FE' & 105.000 & 62.500 & 0,89 & 121.438 \\
10 & Glukosa 'DE' & 121.454 & 62.500 & 0,89 & 130.607 \\
11 & Penambah Aroma 'A' & 1.396 & 50.000 & 0,89 & 12.524 \\
12 & Penambah Aroma 'B' & 830 & 62.500 & 0,89 & 10.797 \\
13 & Rempah 'A' & 81.220 & 50.000 & 0,89 & 95.529 \\
14 & Rempah 'B' & 2.870 & 50.000 & 0,89 & 17.958 \\
\hline
\end{tabular}

Sumber : Data sekunder diolah, 2010

Hasil perhitungan EOQ pada tabel 6 adalah hasil paling ekonomis yang harus dilakukan oleh PT. Puspa Madu Sari dalam setiap kali melakukan pemesanan persediaan, karena pada hasil perhitungan tersebut perusahaan akan memperoleh efisensi baik dari segi jumlah persediaan maupun dari segi jumlah biaya yang harus dikeluarkan. 


\section{Analisis Persediaan Menggunakan EOQ Menghitung Pesanan Optimum}

Suatu pesanan harus dipertimbangkan dan harus dicari kapasitas yang paling ekonomis dalam setiap periodenya, sehingga barang yang akan dipesan sesuai dengan apa yang dibutuhkan dalam arti tidak akan kekurangan dan tidak kelebihan terlalu banyak. Pesanan yang paling optimal adalah pada saat biaya pesan per periode sama dengan biaya simpan per periode. Apabila perusahaan melakukan perhitungan jumlah pemesanan dengan menggunakan metode EOQ, maka perusahaan akan memperoleh jumlah pemesanan yang paling optimal untuk masing-masing bahan sebagai berikut.

Tabel 7. Jumlah Pesanan Ekonomis PT. Puspa Madu S
\begin{tabular}{|l|c|}
\hline \multicolumn{1}{|c|}{ Jenis Bahan } & Jumlah (gram) \\
\hline Terigu & 274.203 \\
Telur & 129.122 \\
Gula 'GP' & 274.243 \\
Gula 'PS' & 147.515 \\
Gula 'SJ' & 208.592 \\
Mentega 'BB' & 408.375 \\
Mentega 'B' & 203.053 \\
Glukosa 'GE' & 188.562 \\
Glukosa 'FE', & 121.438 \\
Glukosa 'DE' & 130.607 \\
Penambah Aroma 'A' & 12.524 \\
Penambah Aroma 'B' & 10.797 \\
Rempah 'A' & 95.529 \\
Rempah 'B' & 17.958 \\
\hline
\end{tabular}

Sumber : Data sekunder diolah, 2010

Jumlah pesanan masing-masing bahan baku pada tabel 7 yang paling optimal. Pada jumlah tersebut PT. Puspa Madu Sari memperoleh hasil yang paling efisien karena jumlah pemesanan benar-benar sesuai dengan kebutuhan dalam setiap periodenya.

\section{Menghitung Biaya Pesan Optimum Persediaan}

Biaya pesan yang optimum ini dapat digunakan sebagai persiapan untuk melakukan pemesanan berikutnya. Biaya pesan optimum PT. Puspa Madu Sari pada periode 2009 adalah sebagai berikut: 
Tabel 8. Biaya Pesan Optimum PT. Puspa Madu Sari periode 2009

\begin{tabular}{|l|c|}
\hline \multicolumn{1}{|c|}{ Jenis Bahan } & Jumlah (Rp) \\
\hline Terigu & 1.100 .187 \\
Telur & 287.295 \\
Gula 'GP' & 366.114 \\
Gula 'PS' & 328.225 \\
Gula 'SJ' & 185.648 \\
Mentega 'BB' & 545.181 \\
Mentega 'B' & 180.716 \\
Glukosa 'GE' & 587.370 \\
Glukosa 'FE' & 54.040 \\
Glukosa 'DE' & 58.120 \\
Penambah Aroma 'A' & 5.573 \\
Penambah Aroma 'B' & 4.805 \\
Rempah 'A' & 42.511 \\
Rempah 'B' & 7.991 \\
\hline \multicolumn{2}{|c|}{ Jumlah } \\
\hline
\end{tabular}

Sumber : Data sekunder diolah, 2010

Angka-angka pada tabel 8 adalah biaya pesan optimum untuk masing-masing bahan baku yang dicapai perusahaan apabila melakukan pemesanan sesuai dengan jumlah pemesanan ekonomis. Dengan biaya pesan optimum, berarti perusahaan telah memaksimalkan pemesanan sesuai dengan kebutuhan setiap periodenya.

\section{Menghitung Biaya Simpan Optimum Persediaan}

Perhitungan biaya simpan yang optimum harus dilakukan PT. Puspa Madu Sari agar pemborosan biaya tidak terjadi, tempat yang disewa untuk penyimpanan tidak kelebihan atau kekurangan dan sesuai dengan biaya yang telah dikeluarkan. Untuk mengetahui biaya simpan yang optimum dilakukan perhitungan yang hasilnya sebagai berikut. 
Tabel 9. Biaya Simpan Optimum

PT. Puspa Madu Sari periode 2009

\begin{tabular}{|c|c|}
\hline Jenis Bahan & Jumlah (Rp) \\
\hline $\begin{array}{l}\text { Terigu } \\
\text { Telur } \\
\text { Gula 'GP' } \\
\text { Gula 'PS' } \\
\text { Gula 'SJ' } \\
\text { Mentega 'BB' } \\
\text { Mentega 'B' } \\
\text { Glukosa 'GE' } \\
\text { Glukosa 'FE' } \\
\text { Glukosa 'DE' } \\
\text { Penambah Aroma 'A' } \\
\text { Penambah Aroma 'B' } \\
\text { Rempah 'A' } \\
\text { Rempah 'B' }\end{array}$ & $\begin{array}{r}1.100 .187 \\
287.295 \\
366.114 \\
328.220 \\
185.646 \\
545.181 \\
180.718 \\
587.370 \\
54.040 \\
58.120 \\
5.573 \\
4.805 \\
42.510 \\
7.991\end{array}$ \\
\hline Jumlah & 3.753 .770 \\
\hline
\end{tabular}

Angka-angka pada tabel 9 adalah hasil perhitungan untuk biaya simpan optimum masing-masing bahan baku yang dihitung sesuai dengan ketentuan pada model EOQ yaitu antara biaya pesan optimum dengan biaya simpan optimum menunjukkan posisi yang sama, sehingga efiisensi diperoleh baik dari biaya pesan maupun biaya simpan.

\section{Menghitung Total Biaya Persediaan}

Biaya total persediaan minimum akan mempermudah perusahaan dalam menyediakan biaya untuk periode berikutnya dengan lebih efisien. Total biaya persediaan minimum PT. Puspa Madu Sari apabila dihitung dengan model EOQ adalah sebagai berikut.

Tabel 10. Total Biaya Persediaan (minimum)

PT. Puspa Madu Sari periode 2009

\begin{tabular}{|l|c|}
\hline \multicolumn{1}{|c|}{ Jenis Bahan } & Jumlah (Rp) \\
\hline Terigu & 2.200 .374 \\
Telur 'GP' & 574.590 \\
Gula 'GP' & 732.228 \\
Gula 'PS' & 656.445 \\
Gula 'SJ' & 371.294 \\
Mentega 'BB' & 1.090 .362 \\
Mentega 'B' & 361.434 \\
Glukosa 'GE' & 1.174 .740 \\
Glukosa 'FE' & 108.080 \\
Glukosa 'DE' & 116.240 \\
Penambah Aroma 'A' & 11.146 \\
Penambah Aroma 'B' & 9.610 \\
Rempah 'A' & 85.021 \\
Rempah 'B' & 15.982 \\
\hline \multicolumn{2}{|c|}{ Jumlah } \\
\hline
\end{tabular}

Sumber : Data sekunder diolah, 2010

Angka-angka pada tabel 10 adalah biaya total persediaan untuk masing-masing bahan baku yang dihitung dengan model EOQ. Biaya tersebut merupakan jumlah biaya 
minimum yang harus dikeluarkan oleh perusahaan untuk pemesanan bahan maupun untuk penyimpanan bahan dalam satu periode.

\section{Menghitung Frekuensi Pemesanan Optimum}

Setiap kali mendatangkan barang persediaan harus disesuaikan dengan kebutuhannya, untuk itu harus dilakukan perhitungan yang tepat kapan harus melakukan pemesanan barang persediaan yaitu dengan menghitung frekuensi pemesanan yang optimum. Frekuensi pemesanan optimum pada PT. Puspa Madu Sari yang sesuai dengan perhitungan model EOQ adalah sebagai berikut;

Tabel 11. Frekuensi pemesanan persediaan optimum

PT. Puspa Madu Sari periode 2009

\begin{tabular}{|l|c|}
\hline \multicolumn{1}{|c|}{ Jenis Bahan } & Frekuensi \\
\hline Terigu & 9 \\
Telur & 5 \\
Gula 'GP' & 3 \\
Gula 'PS' & 5 \\
Gula 'SJ' & 2 \\
Mentega 'BB' & 3 \\
Mentega 'B' & 2 \\
Glukosa 'GE' & 7 \\
Glukosa 'FE' & 1 \\
Glukosa 'DE' & 1 \\
Penambah Aroma 'A' & 1 \\
Penambah Aroma 'B' & 1 \\
Rempah 'A' & 1 \\
Rempah 'B' & 1 \\
\hline
\end{tabular}

Sumber : Data sekunder diolah, 2010

\section{Menghitung Jarak Siklus (waktu)}

Menghitung jarak siklus waktu sangat diperlukan oleh perusahaan agar tidak terjadi kelangkaan stock persediaan adalah sebagai berikut.

Tabel 12. Jarak Siklus (waktu) Pemesanan

Persediaan PT. Puspa Madu Sari periode 2009

\begin{tabular}{|l|c|}
\hline \multicolumn{1}{|c|}{ Jenis Bahan } & Jarak Siklus \\
\hline Terigu & 0,12 \\
Telur & 0,26 \\
Gula 'GP' & 0,49 \\
Gula 'PS' & 0,22 \\
Gula 'SJ' & 0,86 \\
Mentega 'BB' & 0,34 \\
Mentega 'B' & 0,69 \\
Glukosa 'GE' & 0,14 \\
Glukosa 'FE' & 1,16 \\
Glukosa 'DE' & 1,08 \\
Penambah Aroma 'A' & 8,97 \\
Penambah Aroma 'B' & 13,00 \\
Rempah 'A' & 1,17 \\
Rempah 'B' & 6,25 \\
\hline
\end{tabular}

Sumber : Data sekunder diolah, 2010 
Pada tabel 12 menunjukkan jarak siklus waktu optimal pemesanan masing-masing bahan persediaan yang sebaiknya dilakukan oleh PT. Puspa Madu Sari. Misalnya untuk terigu, jarak siklus waktu yang optimal adalah 0,12 atau 43 hari, jarak siklus waktu untuk gula 'PS' adalah 0,22 atau 80 hari, jarak siklus waktu untuk glukosa "GE" adalah 0,14 atau 51 hari.

\section{Perbandingan Efisiensi Sebelum dan Setelah Menggunakan Model EOQ pada PT. Puspa Madu Sari}

Perbandingan sebelum dan setelah penggunaan model EOQ dalam manajemen persediaan dimaksudkan agar perusahaan dapat mengetahui efektifitas dan efisiensi kebijakan menejemen persediaan yang telah ditetapkan oleh perusahaan.

Tabel 4.13 Perbandingan Jumlah Unit setiap kali Order

Pada PT. Puspa Madu Sari

\begin{tabular}{|l|l|c|c|c|}
\hline No & \multicolumn{1}{|c|}{ Jenis Bahan } & $\begin{array}{c}\text { Kebijakan } \\
\text { Perusahaan (garam) }\end{array}$ & EOQ (gram) & Selisih (gram) \\
\hline 1 & Terigu & $50.879,55$ & 274.203 & $-223.323,45$ \\
2 & Telur 'GP' & $10.094,24$ & 129.122 & $-119.027,76$ \\
3 & Gula 'GP' & 111.560 & 274.243 & -162.683 \\
4 & Gula 'PS' & $53.797,50$ & 147.515 & $-93.717,50$ \\
5 & Gula 'SJ' & 118.676 & 208.592 & -127.916 \\
6 & Mentega 'BB' & $26.687,40$ & 408.375 & $-289.634,60$ \\
7 & Mentega 'B' & $57.326,91$ & 203.053 & $-176.365,73$ \\
8 & Glukosa 'GE' & 17.500 & 188.562 & $-131.235,09$ \\
9 & Glukosa 'FE' & $20.242,33$ & 121.438 & -103.938 \\
10 & Glukosa 'DE' & 465,33 & 130.607 & $-110.364,67$ \\
11 & Penambah Aroma 'A' & 415 & 12.524 & $-12.058,67$ \\
12 & Penambah Aroma 'B' & 20.305 & 10.797 & -10.382 \\
13 & Rempah 'A' & 1.435 & 95.529 & -75.224 \\
14 & Rempah 'B' & \multicolumn{3}{|c}{} \\
\hline
\end{tabular}

Sumber : Data sekunder diolah, 2010

Pada tabel 13 terlihat perbedaan yang cukup signifikan antara jumlah masing-masing persediaan bahan yang dipesan per order, antara model EOQ dan kebijakan yang ditetapkan oleh perusahaan. Misalnya terigu terdapat selisih sebanyak 223.323,45 gram. Adanya perbedaan dalam jumlah pembelian bahan tersebut akan mempengaruhi biaya pemesanan dan biaya penyimpanannya. Berdasarkan data yang diperoleh, maka dapat dibandingkan antara biaya persediaan akibat kebijakan PT. Puspa Madu Sari dengan biaya persediaan yang berdasarkan jumlah pemesanan yang ekonomis seperti terlihat pada tabel berikut. 
Tabel 14 Perbandingan Biaya Pesan

Pada PT. Puspa Madu Sari

\begin{tabular}{|l|l|c|r|r|}
\hline No & \multicolumn{1}{|c|}{ Jenis Bahan } & $\begin{array}{c}\text { Kebijakan } \\
\text { Perusahaan } \\
\mathbf{( R p )}\end{array}$ & EOQ (Rp) & Selisih (Rp) \\
\hline 1 & Terigu & 660.000 & 1.100 .187 & -440.187 \\
2 & Telur & 735.000 & 287.295 & 447.705 \\
3 & Gula 'GP' & 300.000 & 366.114 & -66.114 \\
4 & Gula 'PS' & 180.000 & 328.225 & -148.225 \\
5 & Gula 'SJ' & 240.000 & 185.648 & 54.325 \\
6 & Mentega 'BB' & 625.000 & 545.181 & 79.819 \\
7 & Mentega 'B' & 276.000 & 180.716 & 506.784 \\
8 & Glukosa 'GE' & 375.000 & 587.370 & -311.370 \\
9 & Glukosa 'FE' & 375.000 & 54.040 & 320.960 \\
10 & Glukosa 'DE' & 150.000 & 58.120 & 316.880 \\
11 & Penambah Aroma 'A' & 125.000 & 5.573 & 144.427 \\
12 & Penambah Aroma 'B' & 200.000 & 4.805 & 120.195 \\
13 & Rempah 'A' & 100.000 & 42.511 & 157.489 \\
14 & Rempah 'B' & $\mathbf{5 . 0 2 8 . 5 0 0}$ & $\mathbf{3 . 7 5 3 . 7 7 6}$ & $\mathbf{1 . 2 7 4 . 7 2 4}$ \\
\hline \multicolumn{2}{|c|}{ Jumlah } &
\end{tabular}

Sumber : Data sekunder diolah, 2010

Tabel 14 memperlihatkan perbandingan biaya pesan antara perhitungan biaya pesan apabila menggunakan model EOQ, dengan biaya pesan yang ditetapkan oleh kebijakan perusahaan. Dari tabel ini dapat diketahui bahwa secara keseluruhan biaya pesan dengan model EOQ jauh lebih rendah dari biaya pesan kebijakan perusahaan, walaupun untuk biaya pesan bahan tertentu pada kebijakan perusahaan nilai nominalnya lebih rendah. Misalnya pada biaya pesan untuk telur lebih rendah sebanyak Rp 447.705,00, gula 'SJ' lebih rendah sebanyak Rp 54.325,00, dan mentega ' $B$ ' lebih rendah sebayak Rp 506.784,00

Sedangkan untuk perbandingan biaya simpan dapat dilihat pada tabel berikut ini.

Tabel 15 Perbandingan Biaya Simpan Pada PT. Puspa Madu Sari

\begin{tabular}{|l|l|c|c|c|}
\hline No & \multicolumn{1}{|c|}{ Jenis Bahan } & $\begin{array}{c}\text { Kebijakan } \\
\text { Perusahaan (Rp) }\end{array}$ & EOQ (Rp) & Selisih (Rp) \\
\hline 1 & Terigu & $1.992 .443,18$ & 1.100 .187 & $882.256,18$ \\
2 & Telur & $440.209,81$ & 287.295 & $152.914,81$ \\
3 & Gula 'GP' & 496.442 & 366.114 & 130.328 \\
4 & Gula 'PS' & $574.557,30$ & 328.220 & $246.337,30$ \\
5 & Gula 'SJ' & $215.404,92$ & 185.646 & $29.758,92$ \\
6 & Mentega 'BB' & $1.056 .789,56$ & 545.181 & $511.608,56$ \\
7 & Mentega 'B' & $261.268,37$ & 180.718 & $80.550,37$ \\
8 & Glukosa 'GE' & $1.173 .481,85$ & 587.370 & $586.111,85$ \\
9 & Glukosa 'FE' & 93.450 & 54.040 & 39.410 \\
10 & Glukosa 'DE' & $108.094,04$ & 58.120 & $49.974,04$ \\
11 & Penambah Aroma 'A' & $1.242,43$ & 5.573 & $-4.330,57$ \\
12 & Penambah Aroma 'B' & 738,70 & 4.805 & -4.066 .30 \\
13 & Rempah 'A' & $72.285,80$ & 42.510 & $29.775,80$ \\
14 & Rempah 'B' & $2.554,30$ & 7.991 & $-5.436,70$ \\
\hline \multicolumn{2}{|c|}{ Jumlah } & $\mathbf{6 . 4 8 8 . 9 6 2 , 2 6}$ & $\mathbf{3 . 7 5 3 . 7 7 0}$ & $\mathbf{2 . 7 3 5 . 1 9 2 , 2 6}$ \\
\hline
\end{tabular}


Sumber : Data sekunder diolah, 2010

Tabel 15 memperlihatkan perbandingan biaya simpan yang dihitung dengan model EOQ dan biaya pesan kebijakan perusahaan. Secara keseluruhan biaya pesan yang dihitung dengan menggunakan model EOQ jauh lebih rendah bila dibandingkan dengan biaya pesan yang menjadi kebijakan perusahaan. Misalnya terigu, biaya simpanya lebih rendah sebanyak Rp 882.256,18, gula 'GP' lebih rendah sebayak Rp 130.328,00. Perbedaan jumlah biaya pesan dan biaya simpan yang dihitung dengan model EOQ dan kebijakan perusahaan akan mempengaruhi total biaya persediaan yang perbandingannya dapat dilihat pada tabel berikut ini.

Tabel 4.16 Perbandingan Total Persediaan Bahan Pada PT. Puspa Madu Sari

\begin{tabular}{|l|l|c|c|c|}
\hline No & \multicolumn{1}{|c|}{ Jenis Bahan } & $\begin{array}{c}\text { Kebijakan } \\
\text { Perusahaan (Rp) }\end{array}$ & EOQ (Rp) & Selisih (Rp) \\
\hline 1 & Terigu & $2.652 .443,18$ & 2.200 .374 & $452.069,18$ \\
2 & Telur & $1.175 .209,81$ & 574.590 & $600.619,81$ \\
3 & Gula 'GP' & 796.442 & 732.228 & 64.214 \\
4 & Gula 'PS' & $754.557,30$ & 656.445 & $98.112,30$ \\
5 & Gula 'SJ' & $455.404,92$ & 371.294 & $84.110,92$ \\
6 & Mentega 'BB' & $1.681 .789,56$ & 1.090 .362 & $591.427,56$ \\
7 & Mentega 'B' & $948.768,37$ & 361.434 & $587.334,37$ \\
8 & Glukosa 'GE' & $1.449 .481,85$ & 1.174 .740 & $274.741,85$ \\
9 & Glukosa 'FE' & 468.450 & 108.080 & 360.370 \\
10 & Glukosa 'DE' & $483.094,04$ & 116.240 & $366.854,04$ \\
11 & Penambah Aroma 'A' & $151.242,43$ & 11.146 & $140.096,43$ \\
12 & Penambah Aroma 'B' & $125.738,70$ & 9.610 & $116.128,70$ \\
13 & Rempah 'A' & $272.285,80$ & 85.021 & $187.264,80$ \\
14 & Rempah 'B' & $102.554,30$ & 15.982 & $86.572,30$ \\
\hline \multicolumn{2}{|c|}{ Jumlah } & $\mathbf{1 1 . 5 1 7 . 4 6 2 , 2 6}$ & $\mathbf{7 . 5 0 7 . 5 4 6 , 0 0}$ & $\mathbf{4 . 0 0 9 . 9 1 6 , 2 6}$ \\
\hline
\end{tabular}

Sumber : Data sekunder diolah, 2010

Tabel 16 merupakan hasil perhitungan yang memperlihatkan perbedaan jumlah total biaya persediaan yang dihitung dengan model EOQ dan jumlah biaya persediaan yang ditetapkan perusahaan. Penerapan jumlah pemesanan yang ekonomis ternyata mempunyai total biaya persediaan lebih rendah yaitu sebesar Rp 7.507.546,00 dibandingkan dengan kebijakan pengadaan persediaan bahan yang ditetapkan perusahaan yaitu sebesar Rp 11.517.462,26 (dibulatkan menjadi Rp 11.517.462,00) sehingga dengan diterapkannya metode EOQ ini perusahaan akan dapat meminimalkan total biaya persediaan sebesar Rp 4.009.916,00 per tahun atau sebesar 34,8\%.

Perbedaan jumlah pemesanan per order yang ditetapkan dengan model EOQ dan kebijakan perusahaan berpengaruh pada berbedaan frekuensi pemesanan persediaan. Perbandingan frekuensi pemesanan persediaan yang terjadi selama periode 2009 pada PT. Puspa Madu Sari dapat dilihat pada tabel berikut ini. 
Tabel 17 Perbandingan Frekuensi Pemesanan Pada PT. Puspa Madu Sari

\begin{tabular}{|l|l|c|c|c|}
\hline No & \multicolumn{1}{|c|}{ Jenis Bahan } & $\begin{array}{c}\text { Kebijakan } \\
\text { Perusahaan }\end{array}$ & EOQ & Selisih \\
\hline 1 & Terigu & 44 & 9 & 39 \\
2 & Telur & 49 & 5 & 44 \\
3 & Gula 'GP' & 5 & 3 & 2 \\
4 & Gula 'PS' & 12 & 5 & 7 \\
5 & Gula 'SJ' & 3 & 3 & 1 \\
6 & Mentega 'BB' & 10 & 2 & 7 \\
7 & Mentega 'B' & 23 & 1 & 9 \\
8 & Glukosa 'GE' & 6 & 1 & 16 \\
9 & Glukosa 'FE' & 6 & 1 & 5 \\
10 & Glukosa 'DE' & 3 & 1 & 2 \\
11 & Penambah Aroma 'A' & 2 & 1 & 1 \\
12 & Penambah Aroma' 'B' & 4 & 1 & 3 \\
13 & Rempah 'A' & 2 & & 1 \\
14 & Rempah 'B' & & & 5 \\
\hline
\end{tabular}

Sumber : Data sekunder diolah, 2010

Perbedaan frekuensi pemesanan persediaan antara model EOQ dan kebijakan perusahaan berpengaruh pada jumlah biaya pemesanan dan biaya penyimpanan yang harus ditanggung. Selain itu, frekuensi pemesanan juga mempengaruhi kelancaran proses produksi. Pada jumlah frekuensi pemesanan yang tepat persediaan tidak terlalu lama disimpan namun selalu tersedia untuk menunjang proses produksi, sehinggga kualitas persediaan bahan menjadi lebih terjamin.

\section{Pembahasan Tingkat Efisiensi Manajemen Persediaan Bahan Baku Yang Diterapkan PT. Puspa Madu Sari dengan Model EOQ}

Hasil perbandingan menunjukkan bahwa dari sisi pembelian bahan, perusahaan belum menerapkan efisiensi secara optimal. Hal ini terlihat dari perhitungan yang berdasarkan jumlah pemesanan yang ekonomis terdapat perbedaan jumlah unit untuk setiap kali pemesanan (tabel 13). Pada tabel 13 terlihat bahwa kebijakan jumlah pemesanan yang diterapkan oleh perusahaan jauh lebih lebih rendah dari jumlah pemesanan ekonomis yang seharusnya dilakukan oleh perusahaan.

Perbedaan jumlah unit dalam setiap kali melakukan pemesanan yang dilaksanakan oleh perusahaan dengan jumlah pemesanan ekonomis berakibat pada jumlah biaya pemesanan yang harus ditanggung. Biaya pemesanan yang harus ditanggung perusahaan secara keseluruhan lebih besar jumlahnya yaitu $\mathrm{Rp} 5.028 .500,00$ (lihat tabel 14) dibandingkan dengan jumlah biaya pemesanan pada jumlah yang ekonomis yaitu sebesar Rp 3.753.776,00. Sehingga pada biaya pemesanan pesediaan, penerapan model EOQ lebih efisien sebesar Rp 1.274.724,00.

Perbedaan jumlah jumlah unit dalam setiap kali melakukan pemesanan juga berpengaruh pada jumlah biaya penyimpanan persediaan yang harus ditanggung perusahaan. Biaya penyimpanan persediaan yang harus tanggung perusaahan secara keseluruhan lebih besar jumlahnya yaitu Rp 6.488.962,00 (lihat tabel 15) dibandingkan dengan jumlah biaya penyimpanan untuk pemesanan ekonomis yang jumlahnya hanya sebesar $\mathrm{Rp} 3.753 .770,00$. 
Pada biaya penyimpanan persediaan, penerapan model EOQ menghasilkan efisiensi biaya sebesar Rp 2.735.192,00

Biaya pemesanan dan biaya penyimpanan persediaan merupakan komponen total biaya persediaan yang harus ditanggung perusahaan selama periode tertentu. Dari data yang ada, diketahui jumlah total biaya yang harus ditanggung perusahaan adalah sebesar Rp 11.517.462,00 (lihat tabel 16). Biaya ini jumlahnya jauh lebih besar bila dibandingkan dengan total biaya persediaan apabila perusahaan menggunakan model EOQ yang jumlahnya hanya sebesar Rp 7.507.546,00, ini berarti penerapan menejemen persediaan model EOQ pada PT. Puspa Madu Sari menghasilkan efisiensi biaya persediaan sebesar Rp 4.009.916,00 atau lebih efisiensi sebesar 34,8\% bila dibandingkan dengan kebijakan menejemen persediaan yang selama ini diterapkan oleh PT. Puspa Madu Sari.

Frekuensi pemesanan persediaan yang dilakukan perusahaan juah lebih bayak apabila dibandingkan dengan frekuensi pemesanan persediaa yang dihitung dengan model EOQ. Frekuensi pemesanan ini berpengaruh pada jumlah biaya pemesanan dan jumlah biaya penyimpanan. Selain itu frekuensi pemesana persediaan bahan juga mempengaruhi kualitas persediaan bahan serta kelancaran proses produksi perusahaan.

Untuk itu, perusahaan perlu menjaga efisiensi proses produksi dengan cara menekan pemborosan-pemborosan yang terjadi dengan mengadakan pengawasan terhadap persediaan bahannya. Richardus Eko Indrajit (2003:11) berpendapat mengenai persediaan barang ada sejenis prinsip pengelolaan yang harus dianut, yakni: "penentuan jumlah dan jenis barang yang disimpan dalam persediaan haruslah sedemikian rupa sehingga produksi dan operasi perusahaan tidak terganggu, tetapi dilain pihak sekaligus harus dijaga agar biaya investasi yang timbul dari penyediaan barang tersebut seminimal mungkin."

Salah satu cara yang dapat ditempuh dalam pengelolaan persediaan untuk menekan pemborosan adalah dengan menerapkan metode EOQ dalam menentukan jumlah pembelian bahan. Kegiatan pengelolaan persediaan yang paling efisien membutuhkan kebijakan sebagai pedoman dalam melakukan tindakan. Ketidak tepatan kebijakan yang dirumuskan dapat menimbulkan ketidak efisienan.

Secara keseluruhan penerapan model EOQ pada menejemen persediaan PT. Puspa Madu Sari akan meningkatkan efisiensi biaya persediaan. Akan tetapi, pada PT. Puspa Madu Sari ada persediaan bahan tertentu yang dalam penentuan jumlah pembeliannya tidak dapat dihitung dengan menggunakan model EOQ. Misalnya untuk telur, persedian telur tidak dapat dihitung dengan menggunakan model EOQ karena telur tidak dapat disimpan untuk jangka waktu yang lama atau mudah mengalami penurunan kualitas.

\section{Kesimpulan}

Berdasarkan hasil temuan dan pembahasan hasil temuan mengenai perbandingan efisiensi manajemen persediaan PT. Puspa Madu Sari dengan manajemen persediaan model EOQ, disimpulkan;

1. Total biaya persediaan yang harus dikeluarkan oleh PT. Puspa Madu Sari sebesar Rp 11.517.462,00 sedangkan hasil perhitungan pada model EOQ, total biaya persediaan hanya sebesar Rp 7.507.546,00. Sehingga penerapan model EOQ pada menejemen

\footnotetext{
${ }^{1}$ Eko Indrajit, Richardus dan Richardus Djikopranoto. Loc. Cit . Hal. 11.
} 
persediaan PT. Puspa Madu Sari menghasilkan penghematan biaya persediaan sebesar Rp 4.009.916,00 atau lebih efisien sebesar 34,8\%.

2. Tidak semua persediaan bahan pada PT. Puspa Madu Sari dalam penentuan jumlah pembeliannya dapat dihitung dengan model EOQ karena alasan-alasan tertentu, seperti persediaan telur, penambah aroma 'A', penambah aroma 'B' dan rempah 'B'. Model EOQ tidak dapat diterapkan pada keempat bahan tersebut karena pada model EOQ menunjukkan hasil perhitungan siklus waktu pemesanannya lama, sedangkan bahanbahan tersebut tidak dapat disimpan untuk waktu yang lama.

\section{Rekomendasi}

1. PT. Puspa Madu Sari dapat menerapkan manajemen persediaan model EOQ untuk bahan terigu, gula 'GP', gula 'PS', gula 'SJ', mentega 'BB', mentega'B', glukosa 'GE', glukosa 'FE', glukosa 'DE' dan rempah 'A' agar efisiensi meningkat.

2. Apabila hendak menerapkan metode EOQ dalam penentuan jumlah pembelian persediaan, maka perusahaan hendaknya melakukan penyesuaian terutama pada parameter-parameter yang ada dalam perhitungan EOQ. Parameter tersebut antara lain adalah perkiraan biaya pesan dan biaya simpan. PT. Puspa Madu Sari juga harus memperhatikan asumsi-asumsi yang terdapat pada model EOQ karena asumsi-asumsi pada model EOQ merupakan rambu-rambu yang harus dipenuhi agar perusahaan dapat menerapkan EOQ dalam memanajemen persediaannya.

\section{DAFTAR PUSTAKA}

Aditomo, Prakoso, 2007. Efisiensi Manajemen Persediaan Dengan Menggunakan Economic Order Quantity Dalam Perolehan Laba (Study Kasus Pada CV. Nandi Astika Wonogiri), Skripsi tidak dipublikasikan, Fakultas Ekonomi, UKSW. Salatiga.

Azwar, Saifuddin, 2001. Metode penelitian, PUSTAKA PELAJAR, Yogyakarta.

Eko Indrajit, Richardus dan Richardus Djikopranoto, 2003. Manajemen Persediaan, PT Grasindo, Jakarta.

Giosudarmo, Indriyo dan agus Mulyono, 2000. Manajemen Bisnis Logistik, BPFE, Yogyakarta.

Kountur, Ronny, 2004. Metode Penelitian: Untuk Penulisan Skripsi dan Tesis, PPM, Jakarta.

Lambert, Douglas M, 1998. Fundamentals of Logistics Managemen, McGraw-Hill Co - Singapore.

Kurmasela, Ellen Novilensia, 2007. Manajemen Sediaan Bahan Baku Kapas Pada Departemen Spinning-PT Daya Manunggal Salatiga, Skripsi tidak dipublikasikan. Progdi Pendidikan Ekonomi - Fakultas Keguruan dan Ilmu Pendidikan, UKSW, Salatiga.

Mantra, Ida Bagoes, 2004. Filsafat Penelitian \& Metode Penelitian Sosial, PUSTAKA PELAJAR, Yogyakarta.

Moleong, Lexy J, 2001. Metodologi Penelitian Kualitatif, PT. Remaja Rosdakarya, Bandung.

Nasution, Arman Hakim dan Yudha Prasetyawan, 2008. Perencanaan Pengendalian Produksi, GRAHA ILMU, Yogyakarta. 
Purwati, Yenny, 2004, Manajemen Operasi. Fakultas Ekonomi Universitas Kristen Satya Wacana, Salatiga.

Render, Barry dan Jay Heizer, 2001. Prinsip-Prinsip Manajemen Operasi, Salemba Empat, Jakarta.

Surja, Fany Darmawati, 2002. Analisis Pengendalian Persediaan Bahan Baku Dengan Menggunakan Model EOQ Pada Perusahaan sandal OMICA Semarang, Skripsi Tidak dipublikasikan, Fakultas Ekonomi, UKSW, Salatiga.

Tisnawati Sule, Erni dan Kurniawan Saefullah, 2005. Pengantar Manajemen, Kencana, Jakarta.

Yamit, Zulian, 2005. Manajemen Persediaan, EKONISIA, Yogyakarta. 2000. Manajemen Produksi dan Operasi, EKONISIA, Yogyakarta. 